\title{
Keanekaragaman dan Kelimpahan Tumbuhan Air di Subak Pulagan, Tampaksiring, Gianyar, Bali
}

\author{
Ni Putu Bella Yuliana Dewi a*, I Wayan Arthana a, Ni Putu Putri Wijayanti a \\ a Program Studi Manajemen Sumberdaya Perairan, Fakultas Kelautan dan Perikanan, Universitas Udayana, Badung, Bali-Indonesia \\ * Penulis koresponden. Tel.: +62-858-471-648-36 \\ Alamat e-mail: putubella1@gmail.com
}

Diterima (received) 20 Juni 2018; disetujui (accepted) 2 Agustus 2018

\begin{abstract}
This study aimed to determine the diversity, abundance and dominance of aquatic plants, relation to water quality to aquatic plants, and the relation of aquatic biota to aquatic plants. This research used observation and purposive method. The highest abundance value of aquatic plants found in station 1 (upper area) of $4034 \mathrm{ind} / \mathrm{m} 2$ with the type of aquatic plant was (Salvinia molesta). The index value of diversity ranged from $0,6628-0,8985$, with the highest index found in station 2 (middle) of 0,8985. The dominance index value ranged from 0,4537-0,6127, with the highest dominant index found in station 3 (lower area) with species dominated by (Pistia stratiotes). The relation of aquatic plants with temperature showed correlation value of $r=-0,9967$ (very strong). The relation with other water quality parameter to aquatic plants showed correlation value which were with $\mathrm{pH}$ of $\mathrm{r}=0,8263$ (very strong), with $\mathrm{DO}$ of $\mathrm{r}=$ 0,7651 (strong), with nitrate of $r=-0,8457$ (very strong), and with phosphate of $r=0,7092$ (strong). Correlation between abundance of biota Aplocheilus panchax to diversity, abundance, and dominance of aquatic plants showed the highest correlation value respectively of $r=0,6344$ (station 1), $r=0,9987$ (station 1), and $r=-0,5688$ (station 3).
\end{abstract}

Keywords: water quality, rice field, Salvinia, Pistia

\begin{abstract}
Abstrak
Penelitian ini bertujuan untuk mengetahui keanekaragaman, kelimpahan dan dominansi tumbuhan air, hubungan kualitas air dengan tumbuhan air serta hubungan biota perairan dengan tumbuhan air. Metode yang digunakan adalah metode observasi dan metode purposive. Nilai kelimpahan tertinggi tumbuhan air terdapat pada stasiun 1 (hulu) sebesar 4034 ind/m2 dengan jenis tumbuhan air kiambang (Salvinia molesta). Nilai indeks keanekaragaman berkisar antara 0,6628-0,8985, dengan nilai indeks keanekaragaman tertinggi terdapat pada stasiun 2 (tengah) sebesar 0,8985. Nilai indeks dominansi berkisar antara 0,4537-0,6127, dengan indeks dominansi tertinggi terdapat pada stasiun 3 (hilir) dengan jenis tumbuhan air yang mendominansi yaitu apu-apu (Pistia stratiotes). Hubungan tumbuhan air dengan suhu menunjukkan nilai $r=-0,9967$ (sangat kuat). Hubungan tumbuhan air dengan parameter kualitas air lainnya menunjukkan nilai korelasi antara lain dengan $\mathrm{pH}$ yaitu $\mathrm{r}=0,8263$ (sangat kuat), dengan $\mathrm{DO}$ yaitu $r=-0,7651$ (kuat), dengan nitrat yaitu $r=-0,8457$ (sangat kuat) dan dengan fosfat yaitu $r=0,7092$ (kuat). Hubungan korelasi antara kelimpahan biota ikan kepala timah (Aplocheilus panchax) terhadap keanekaragaman, kelimpahan, dan dominansi tumbuhan air menunjukkan nilai korelasi tertinggi secara berurutan masing-masing $\mathrm{r}=0$,6344 (stasiun 1), $r=0,9987$ (stasiun 1), $r=-0,5688$ (stasiun 3).
\end{abstract}

Kata Kunci: kualitas air, sawah, kiambang, apu-apu

\section{Pendahuluan}

Sawah merupakan suatu bentuk penggunaan lahan yang pengelolaannya membutuhkan air yang tergenang. Sawah selalu memiliki daerah dan permukaan datar atau yang didatarkan, dan dibatasi oleh pematang untuk menahan air genangan (Siagian, 2015). Sekumpulan sawah yang terdapat di Bali dikenal dengan nama Subak yaitu suatu sistem irigasi yang telah menyatu dengan sosio-kultural masyarakat di Bali. Salah satu subak yang menjadi WBD (Warisan Budaya Dunia) 
adalah Subak Pulagan yang dialiri oleh Daerah Aliran Sungai (DAS) Pakerisan berada di kawasan Kecamatan Tampaksiring Kabupaten Gianyar.

Menurut Aryawan et al, (2013) subak memiliki banyak manfaat yang erat pada produksi pangan, ekosistem lahan sawah beririgasi, dan ritual keagamaan yang terkait dengan budidaya padi. Kegiatan budidaya padi mengakibatkan timbulnya beberapa jenis tumbuhan air yang disebabkan oleh masukan unsur hara yang berlebih dari proses penanaman padi tersebut. Beberapa jenis tumbuhan air yang sering dijumpai antara lain apu-apu, eceng gondok dan Azolla sp. Tumbuhan air efektif meningkatkan kadar oksigen dalam air melalui proses fotosintesis. Karbondioksida dalam proses fotosintesis diserap dan oksigen dilepas ke dalam air. Menurut Suryati (2016), proses fotosintesis mempunyai manfaat penting dalam akuakultur, di antaranya adalah menyediakan sumber bahan organik bagi tumbuhan itu sendiri serta sumber oksigen yang digunakan oleh semua organisme.

\section{Metode Penelitian}

\subsection{Waktu dan Tempat}

Penelitian ini dilakukan di Subak Pulagan, Kecamatan Tampaksiring, Kabupaten Gianyar. Penelitian ini berlangsung dari bulan Januari sampai Februari 2018. Penelitian dilakukan pada tiga stasiun dengan tiga titik di setiap stasiun.

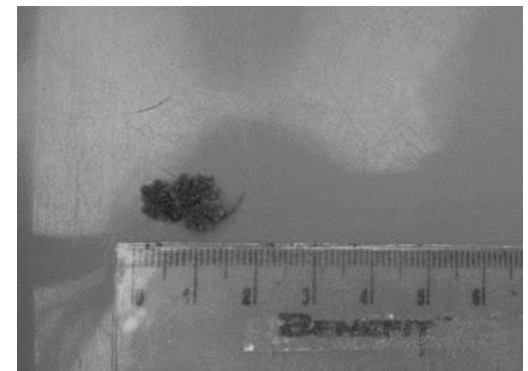

(a)

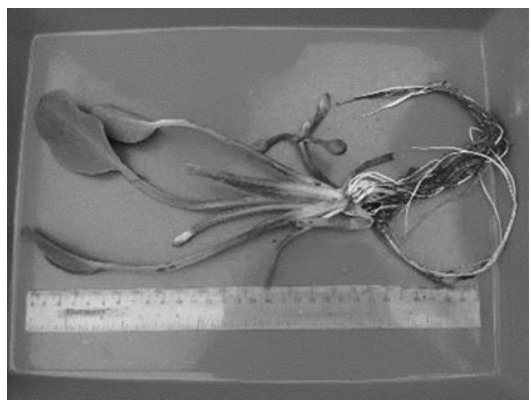

(d)

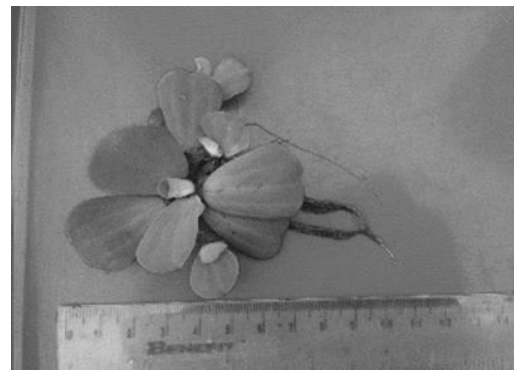

(b)

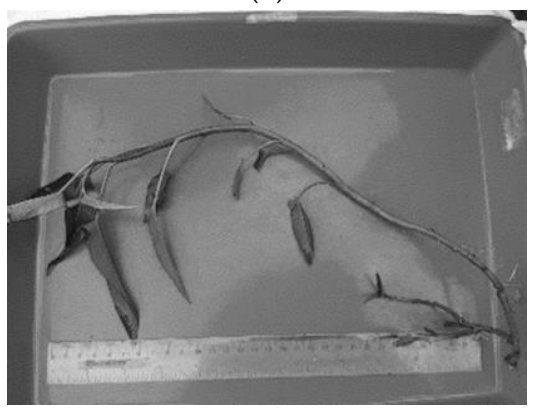

(e)
Lokasi pada stasiun pertama yaitu berada pada daerah hulu sungai, stasiun kedua berada di tengah dan stasiun ketiga berada di daerah hilir sungai.

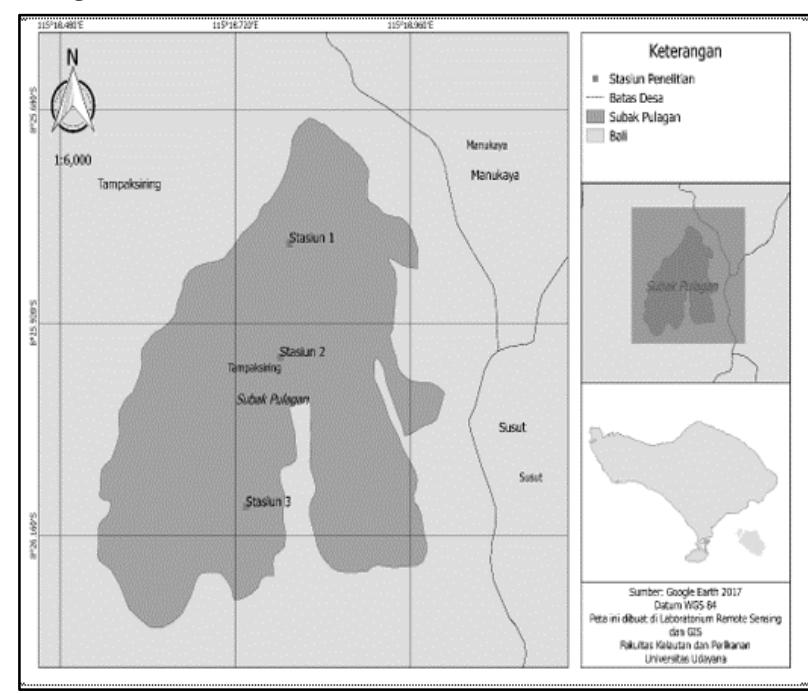

Gambar 1. Peta Lokasi Penelitian

\subsection{Alat dan Bahan}

Alat-alat penelitian yang akan digunakan adalah $\mathrm{pH}$ meter, DO meter, Termometer, spektrofotometri, GPS, alat tulis, meteran, plastik, label, transek $1 \times 1 \mathrm{~m}$, cool box, botol sampel dan buku identifikasi (easy identification of aquatic plants). Bahan-bahan penelitian yang akan digunakan adalah sampel air, tumbuhan air, alkohol $70 \%$ dan es batu.

Gambar 2. Identifikasi tumbuhan air (a) Mata lele (Azolla sp.); (b) Apu-apu (Pistia stratiotes); (c) Kiambang (Salvinia molesta); (d) Eceng gondok (Eichhornia crassipes); (e) Kangkung (Ipomoea reptans, Poir); dan Pegagan (Centella asiatica) 


\subsection{Metode Penelitian}

Metode pengambilan data yan g digunakan adalah metode observasi, yaitu teknik pengumpulan data, dimana peneliti melakukan pengamatan secara langsung ke objek penelitian untuk melihat dari dekat kegiatan yang dilakukan. Metode penentuan stasiun penelitian menggunakan metode Purposive yaitu metode penentuan stasiun dengan pertimbangan-pertimbangan yang telah ditentukan.

\subsection{Analisis Data}

Data yang didapatkan dari penelitian ini yaitu berupa data fisika-kimia air, data tumbuhan air dan data biota air di Subak Pulagan. analisis yang dihitung berupa indeks kelimpahan, indeks keanekaragaman dan indeks dominansi dan diolah menggunakan Microsoft Excel 2016.

\subsubsection{Indeks Kelimpahan}

Kelimpahan merupakan jumlah individu yang menempati wilayah tertentu per satuan luas atau per satuan volume. Mencatat semua jenis tumbuhan air dan biota air dalam bentuk individu maupun koloni dan menghitung kelimpahan jenis dalam satu komunitas dengan rumus (Asus, 2011) yaitu:

$$
\mathrm{Ki}=\mathrm{ni} / \mathrm{A}
$$

Dimana K adalah kelimpahan jenis tumbuhan air (Individu $\left./ \mathrm{m}^{2}\right) ; \mathrm{N}$ adalah jumlah koloni setiap spesies tumbuhan air (Individu); dan A adalah luas transek $\left(\mathrm{m}^{2}\right)$.

\subsubsection{Indeks Keanekaragaman}

Keanekaragaman spesies dapat dikatakan sebagai indikasi banyaknya jenis tumbuhan air dan bagaimana penyebaran jumlah individu pada setiap jenis dan lokasi sampling. Untuk menentukan keanekaragaman dihitung dengan menggunakan formula Shannon-Weaner (Rappe, 2010) berikut:

$\mathrm{H}^{\prime}=-\Sigma(\mathrm{ni} / \mathrm{N}) \ln (\mathrm{ni} / \mathrm{N})$

Dimana $\mathrm{H}^{\prime}$ adalah indeks keanekaragaman jenis; ni adalah jumlah individu jenis ke-i; $\mathrm{N}$ adalah jumlah total individu.

\subsubsection{Indeks Dominansi}

Indeks dominansi untuk menghitung suatu individu yang mendominansi pada suatu wilayah tertentu, indeks dominansi digunakan rumus (Rappe, 2010) sebagai berikut:

$\mathrm{D}=\Sigma(\mathrm{ni} / \mathrm{N})^{2}$

Dimana D adalah indeks dominansi; ni adalah jumlah individu spesies ke-i; dan $\mathrm{N}$ adalah jumlah total spesies.

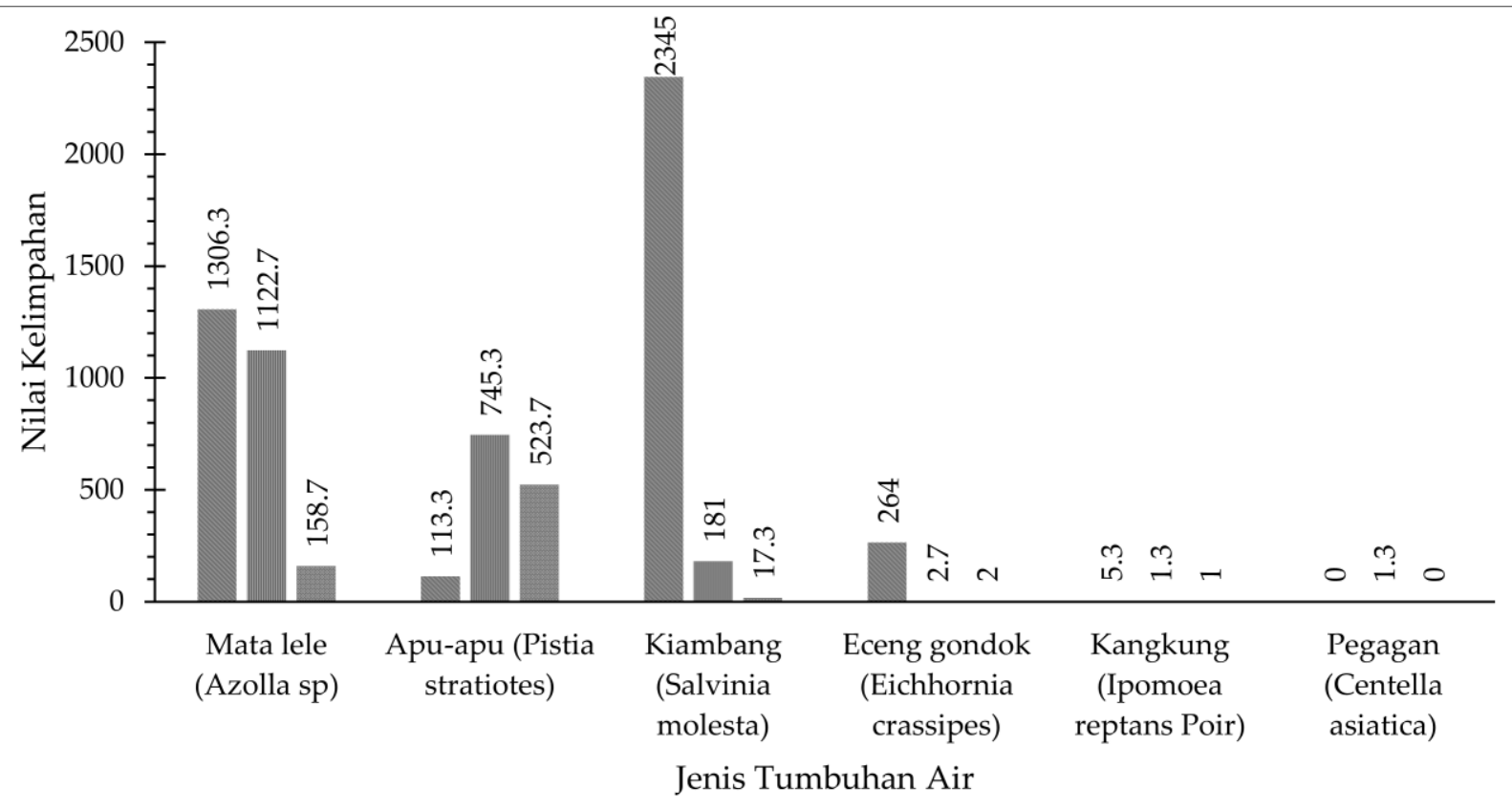

Gambar 3. Nilai Total Kelimpahan Tumbuhan Air di Subak Pulagan Pada Stasiun 1 (国), Stasiun 2 (III), Stasiun 3 (四) 


\section{Hasil dan Pembahasan}

\subsection{Jenis Tumbuhan Air}

Beberapa jenis tumbuhan air yang dijumpai pada saat penelitian berlangsung antara lain mata lele (Azolla sp.), apu-apu (Pistia stratiotes), kiambang (Salvinia molesta), eceng gondok (Eichhornia crassipes), kangkung (Ipomoea reptans Poir), dan pegagan (Centella asiatica). Setiap stasiun penelitian memiliki jenis spesies tumbuhan air yang berbeda, maka dari itu tidak semua jenis tumbuhan air di atas terdapat disetiap stasiun penelitian.

\subsection{Kelimpahan, Keanekaragaman dan Dominansi}

\subsubsection{Kelimpahan}

Total kelimpahan tumbuhan air di Subak Pulagan dapat dilihat pada Gambar 3. Kelimpahan tertinggi terdapat pada spesies Salvinia molesta. Keberadaan Salvinia molesta yang dominan pada stasiun 1, karena menurut Yuliani et al. (2013) jenis ini merupakan tumbuhan air yang memiliki karakteristik laju perkembangbiakan sangat cepat dengan sifat adaptasi yang tinggi di berbagai kondisi lingkungan. Hal ini didukung oleh Rahmansyah dan Maman (2009) yang mengemukakan bahwa Salvinia molesta memiliki tingkat survival yang tinggi pada media yang terkontaminasi. Saru (2013) menyatakan kelimpahan tumbuhan air yang tinggi maka akan menghasilkan serasah daun yang tinggi pula dan dari hasil serah daun yang dihasilkan didegradasi oleh organisme dekomposer menjadi unsur hara.

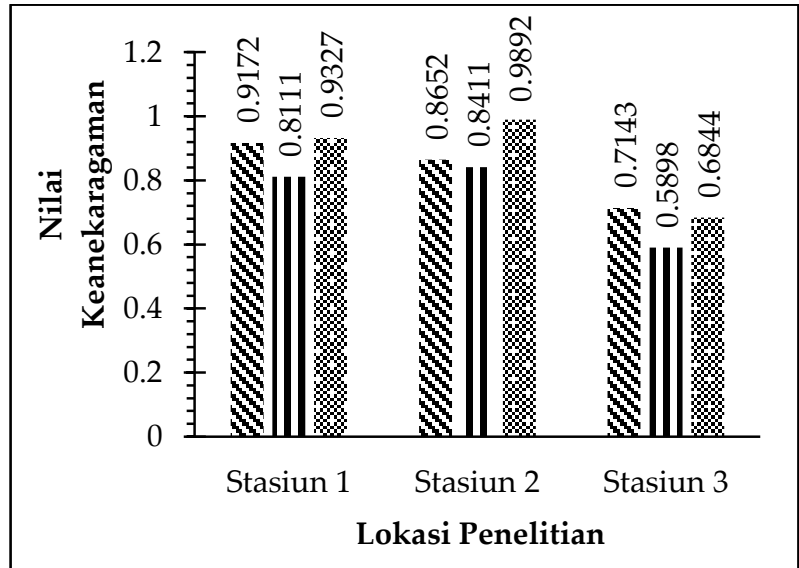

Gambar 4. Nilai Indeks Keanekaragaman Setiap Stasiun Pengulangan 1 (匡), Pengulangan 2 (苗), Pengulangan 3 (国)

3.2.2 Keanekaragaman
Nilai indeks keanekaragaman (Gambar 4) pada stasiun 1 berlokasi di hulu sungai Subak Pulagan yang menunjukkan nilai indeks keanekaragaman tertinggi terdapat pada pengulangan 3 sebesar 0,9327 dan pada pengulangan 2 merupakan nilai terendah yaitu sebesar 0,8111 . Stasiun 2 berlokasi di tengah Subak Pulagan yang memiliki nilai 0,9892 menunjukkan nilai indeks keanekaragaman tertinggi pada pengulangan 3 dan pada pengulangan 2 dengan nilai 0,8411 menunjukkan nilai terendah. Pada stasiun 3 yang berlokasi di daerah hilir sungai Subak Pulagan memiliki nilai tertinggi pada pengulangan 1 dengan nilai 0,7143 dan pada pengulangan 2 dengan nilai 0,5898 merupakan nilai terendah pada stasiun 3 .

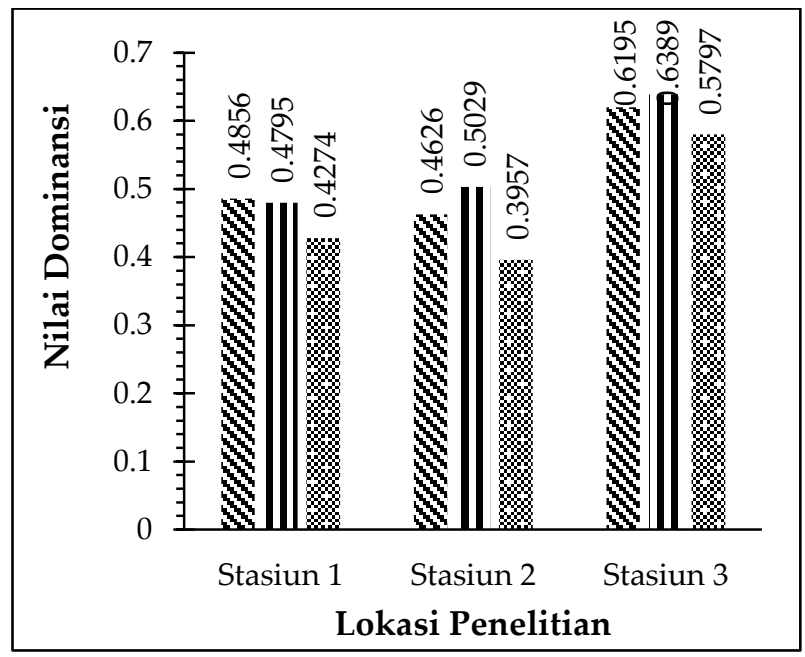

Gambar 5. Nilai Indeks Dominansi Setiap Stasiun Pengulangan 1 (国), Pengulangan 2 (m), Pengulangan 3 (目)

\subsubsection{Dominansi}

Nilai indeks dominansi (Gambar 5) pada stasiun 1 menunjukkan nilai indeks dominansi tertinggi terdapat pada pengulangan 1 sebesar 0,4856 dan pada pengulangan 3 merupakan nilai terendah yaitu sebesar 0,4274. Stasiun 2 memiliki nilai 0,5029 menunjukkan nilai indeks dominansi tertinggi pada pengulangan 2 dan pada pengulangan 3 dengan nilai 0,3957 menunjukkan nilai terendah. Pada stasiun 3 memiliki nilai tertinggi pada pengulangan 2 dengan nilai 0,6389 dan pada pengulangan 3 dengan nilai 0,5797 merupakan nilai terendah.

Menurut Mardiyanti (2013) indeks dominansi digunakan untuk mengetahui kekayaan spesies serta keseimbangan jumlah individu setiap spesies dalam ekosistem. Berdasarkan hasil perhitungan, nilai dominansi di Subak Pulagan berkisar 0,45370,6127. Menurut kriteria Odum (1996) indeks 
dominansi berkisar antara 0,4-0,6. $\mathrm{D}=0,4$ berarti tidak terdapat spesies yang mendominasi spesies lainnya atau struktur komunitas dalam keadaan stabil. $\mathrm{D}=0,6$ berarti terdapat spesies yang mendominasi spesies lainnya, atau struktur komunitas labil karena terjadi tekanan ekologis.

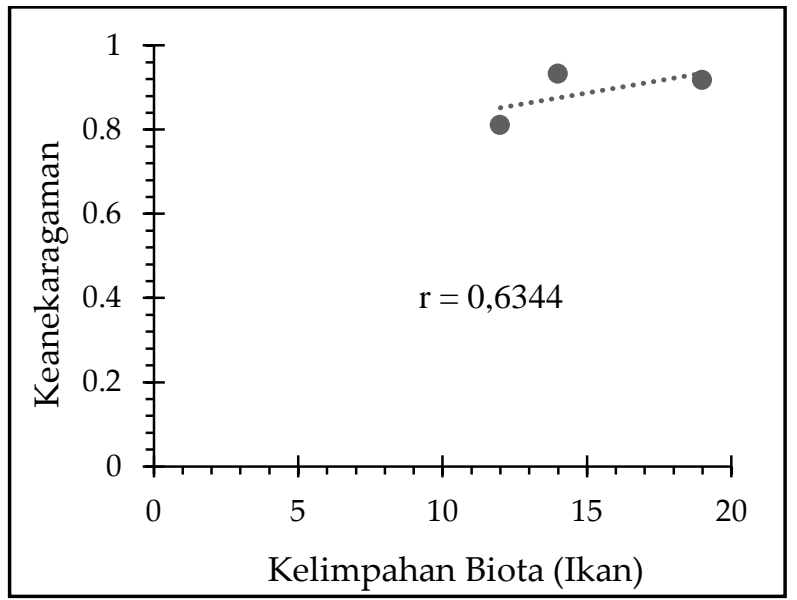

Gambar 7. Korelasi kelimpahan biota (ikan) terhadap keanekaragaman tumbuhan air Stasiun 1.

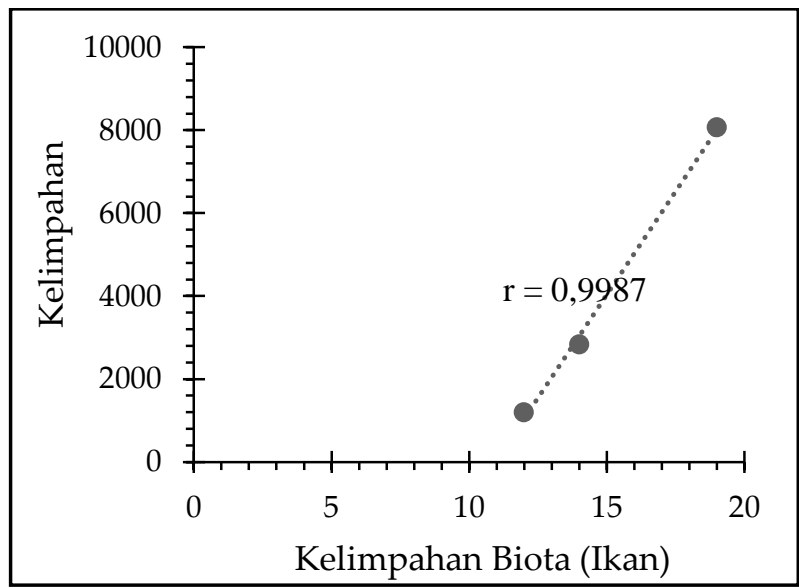

Gambar 8. Korelasi kelimpahan biota (ikan) terhadap kelimpahan tumbuhan air Stasiun 2

\subsection{Kualitas Perairan Subak Pulagan}

\subsubsection{Kualitas Air}

Kualitas air pada perairan Subak Pulagan diukur sebagai data penunjang. Kualitas air yang diukur meliputi parameter fisika seperti suhu dan parameter kimia air seperti $\mathrm{pH}, \mathrm{DO}$, nitrat dan fosfat. Data kualitas air pada setiap stasiunnya secara lengkap dapat dilihat pada (Gambar 6). Suhu tertinggi yaitu sebesar $25,230 \mathrm{C}$ terdapat pada stasiun 3 dan pada stasiun 1 merupakan nilai suhu terendah sebesar 24,630C. Pada stasiun 1 merupakan nilai $\mathrm{pH}$ tertinggi sebesar 7,53 dan nilai $\mathrm{pH}$ terendah dimiliki oleh stasiun 3 . Nilai DO pada stasiun 3 merupakan nilai tertinggi yaitu 7,63 dan nilai DO terendah terdapat pada stasiun 2 dengan nilai 7,23 . Nitrat pada lokasi penelitian terdapat pada stasiun 2 sebesar 6,77 sedangkan untuk nilai nitrat pada stasiun 1 dengan nilai 5,57 merupakan nilai terendah dan kandungan fosfat tertinggi dimiliki oleh stasiun 1 yaitu sebesar 0,61 dan pada stasiun 2 merupakan nilai terendah sebesar 0,50 .

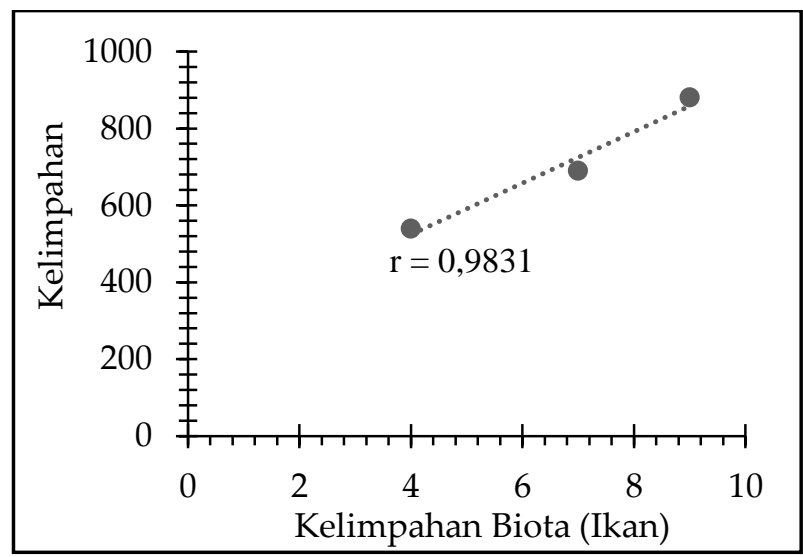

Gambar 9. Korelasi kelimpahan biota (ikan) terhadap kelimpahan tumbuhan air Stasiun 3

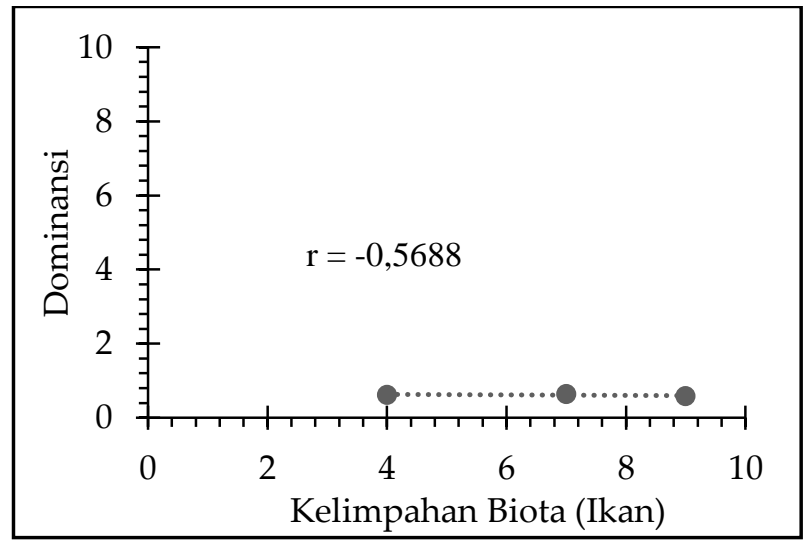

Gambar 10. Korelasi kelimpahan biota (ikan) terhadap dominansi tumbuhan air Stasiun 4

Hubungan suhu terhadap kelimpahan tumbuhan air menunjukkan nilai korelasi $\mathrm{r}=$ 0,9967 yang termasuk dalam kategori sangat kuat. Hal ini sesuai dengan pernyataan Sugiyono (2008) bahwa rentang nilai $0,80-1,00$ termasuk kategori hubungan sangat kuat dan tanda negatif menyatakan adanya korelasi berlawanan antara hubungan suhu terhadap kelimpahan tumbuhan air. Hubungan $\mathrm{pH}$ terhadap kelimpahan tumbuhan air menunjukkan nilai korelasi $\mathrm{r}=$ 0,8263 yang termasuk dalam kategori sangat kuat. Hubungan DO terhadap kelimpahan tumbuhan air menunjukkan nilai korelasi $\mathrm{r}=-0,7651$ yang termasuk dalam kategori kuat. Berdasarkan perhitungan korelasi didapatkan hasil kandungan nitrat di Subak Pulagan memiliki tingkat korelasi $\mathrm{r}$ $=-0,8457$ yang termasuk dalam kategori sangat 
kuat. Hal ini sesuai dengan pernyataan Sugiyono (2008) bahwa rentang nilai 0,80-1,00 termasuk kategori hubungan sangat kuat dan tanda negatif menyatakan adanya korelasi berlawanan antara hubungan nitrat terhadap kelimpahan tumbuhan air.

Perhitungan korelasi kandungan fosfat terhadap kelimpahan tumbuhan air yaitu $\mathrm{r}=$ 0,7092 yang termasuk dalam kategori kuat. Hal ini sesuai dengan pernyataan Sugiyono (2008) bahwa rentang nilai 0,60-0,79 termasuk kategori hubungan kuat dan tanda positif menyatakan adanya korelasi searah antara hubungan fosfat terhadap kelimpahan tumbuhan air.

\subsection{Biota Perairan}

Berdasarkan pengamatan biota perairan yang terdapat di Subak Pulagan. jenis biota yang terdapat disana antara lain Ikan Kepala Timah (Aplocheilus panchax), didapatkan hasil pada pengambilan hari ke-0 nilai tertinggi diperoleh oleh stasiun 1 sebanyak 19 ekor sedangkan nilai terendah terdapat pada stasiun 3 sebanyak 4 ekor. Jumlah yang diperoleh pada pengamatan pada hari ke-14 menunjukkan hasil tertinggi yaitu pada stasiun 1 sebanyak 12 ekor, sedangkan stasiun 3 menunjukkan nilai terendah dengan hasil ikan yang diperoleh sebanyak 7 ekor. Pengamatan pada hari ke-28 menunjukkan hal yang sama dengan stasiun 1 dan stasiun 2 yaitu nilai tertinggi terdapat pada stasiun 1 sebanyak 14 ekor, sedangkan nilai terendah terdapat pada stasiun 3 sebanyak 9 ekor. Menurut Halim (2010), pertumbuhan tumbuhan air dapat mempercepat kehilangan air melalui evapotranspirasi, pendangkalan sungai, tersumbatnya aliran sungai bahkan dapat mengurangi produksi ikan di rawarawa ataupun di danau. Namun berdasarkan hasil pengamatan menunjukkan pernyataan yang berbanding terbalik bahwa semakin banyak kelimpahan tumbuhan air (Gambar 7) semakin banyak pula keberadaan ikan. Hal ini disebabkan karena ikan membutuhkan tumbuhan air sebagai daerah mencari makan (feeding ground), daerah pembesaran (nursery ground), dan daerah pemijahan (spawning ground).

Hubungan korelasi antara kelimpahan biota terhadap keanekaragaman tumbuhan air menunjukkan nilai korelasi tertinggi terdapat pada stasiun 1 (Gambar 7) yaitu $\mathrm{r}=0,6344$ (kuat). Hal ini sesuai dengan pernyataan Sugiyono (2008) bahwa rentang nilai 0,60-0,79 termasuk kategori hubungan kuat dan tanda positif menyatakan adanya korelasi searah antara hubungan $\mathrm{pH}$ terhadap kelimpahan tumbuhan air. Sedangkan nilai korelasi terendah terdapat pada stasiun 2 yaitu $r=0,1285$ (sangat rendah). Hal ini sesuai dengan pernyataan Sugiyono (2008) bahwa rentang nilai 0-0,19 termasuk kategori hubungan sangat rendah.

Hubungan kelimpahan biota terhadap kelimpahan tumbuhan air nilai korelasi tertinggi terdapat pada stasiun 1 yaitu $r=0,9987$ (sangat kuat), sedangkan nilai korelasi terendah terdapat pada stasiun 3 yaitu $r=0,9831$ (sangat kuat). Hal ini sesuai dengan pernyataan Sugiyono (2008) bahwa rentang nilai $0,80-1,00$ termasuk kategori hubungan sangat kuat dan tanda positif menyatakan adanya korelasi searah antara hubungan kelimpahan biota terhadap kelimpahan tumbuhan air.

Hubungan kelimpahan biota air terhadap dominansi tumbuhan air yang nilai korelasi menunjukkan nilai korelasi tertinggi terdapat pada stasiun 3 yaitu $r=-0,5688$ (sedang), sedangkan nilai korelasi terendah terdapat pada stasiun 2 yaitu $r=0,1001$ (sangat rendah). Hal ini sesuai dengan pernyataan Sugiyono (2008) bahwa rentang nilai 0,40-0,59 termasuk kategori hubungan sedang dan tanda negatif menyatakan adanya korelasi berlawanan. Sedangkan rentang nilai 0,00-0,19 termasuk di dalam kategori sangat rendah dan tanda positif menunjukkan adanya korelasi searah antara hubungan kelimpahan biota air terhadap dominansi tumbuhan air.

\section{Simpulan}

Nilai keanekaragaman tumbuhan air di Subak Pulagan sebesar 0,8161 yang berarti tergolong rendah. Spesies Mata Lele (Azolla sp.) merupakan jenis spesies yang memiliki kelimpahan tertinggi sebesar 2587,7 ind $/ \mathrm{m}^{2}$ dan terendah spesies pegagan (Centella asiatica) dengan nilai $1,3 \mathrm{ind} / \mathrm{m}^{2}$. Nilai dominansi tertinggi terdapat di stasiun 3 dengan nilai sebesar 0,6127 yang mengindikasikan adanya dominansi dari suatu spesies di stasiun 3, yaitu spesies jenis Apu-Apu (Pistia stratiotes). Hubungan korelasi antara kualitas air dengan kelimpahan tumbuhan air menunjukkan nilai masing-masing dengan suhu sebesar $\mathrm{r}=-0,9967$, dengan $\mathrm{pH}$ sebesar $\mathrm{r}=0,8263$, dengan $\mathrm{DO} r=-$ 0,7651 , dengan nitrat sebesar $r=-0,8457$ dan 
dengan fosfat sebesar $r=0,7092$. Nilai tersebut menunjukkan adanya hubungan yang kuat antara kualitas air dengan kelimpahan tumbuhan air di Subak Pulagan. Ada korelasi yang cukup kuat antara kelimpahan biota (Aplocheilus panchax) dengan keanekaragaman dan kelimpahan tumbuhan air.

\section{Daftar Pustaka}

Aryawan P. S, Windia, W, \& Wijayanti, P. U. (2013). Peranan Subak dalam aktivitas pertanian padi Sawah (kasus di Subak Dalem, kecamatan Kerambitan, Kabupaten Tabanan). E-Jurnal Agribisnis dan Agrowisata, 2(1), 1-2.

Asus M. S. (2011). Kelimpahan dan komposisi Fitoplankton di Waduk Selorejo Kecamatan Ngantang Kabupaten Malang. Jurnal Perikanan, 4(2), 34-39.

Halim. (2010). Pengelolaan Gulma: Biologi, Klassifikasi, dan Pengendaliannya. Bandung, Indonesia: Unpad Press.

Mardiyanti, D. E., Wicaksono, K. P., \& Baskara, M. (2013). Dinamika keanekaragaman spesies tumbuhan pasca pertanaman padi. Jurnal Produksi Tanaman, 1(1) 24-35.

Odum, E. P. (1996). Fundamentals of Ecology. Dalam Samingan, T (Terj). Dasar-dasar Ekologi. Yogyakarta, Indonesia: Gadjah Mada University Press.
Rahmansyah, M. (2009). Tumbuhan Akumulator untuk Fitoremediasi Lingkungan Tercemar Merkuri dan Sianida Penambangan Emas. Jakarta: LIPI Press.

Rappe, R. A. (2010). Struktur Komunitas Ikan pada Padang Lamun yang Berada di Pulau Barrang Lompo. Jurnal dan Teknologi Kelautan Tropis, 2(2), 6273.

Saru A. (2013). Kontribusi Ekosistem Mangrove dalam Meningkatkan Potensi Sumber daya Perikanan Pesisir dan Laut Secara Berkelanjutan dalam Membangun Sumber Daya Kelautan Indonesia : Gagasan dan Pemikiran Guru Besar Universitas Hasanuddin. Bogor: IPB Press.

Siagian V. (2015). Perkembangan usahatani padi sawah di daerah irigasi Batang Angkola, Sumatera Utara. Pros Sem. Nas. Masy. Biodiv. Indon., 1(5), 1245-1250.

Sugiyono. (2008). Statistika untuk Penelitian. Bandung, Indonesia: CV. Alfabeta.

Suryati, E, Triana, H, Widyastuti, U, \& Tenriulo, A. (2016). Regenerasi dan Perbanyakan Rumput Laut Kappaphycus alvarezii Hasil Transformasi Gen Superoksida Dismutase (MaSOD). Jurnal Riset Akuakultur, 11(4), 321-330.

Yuliani, D. E, Saibun, S., \& Teguh, W. (2013). Analisis kemampuan Kiambang (Salvinia molesta) untuk menurunkan konsentrasi ion logam $\mathrm{Cu}$ (II) pada media tumbuh air. Jurnal Kimia Mulawarman, 10(2), 68-73. 